\title{
Neurosurgery at the University of Miami
}

\author{
Linda Alberga, MS, Ingrid Menendez, AA, Howard J. Landy, MD, Jacques J. Morcos, MD, and \\ Allan D. Levi, MD, PhD
}

Department of Neurological Surgery and The Miami Project to Cure Paralysis, University of Miami Miller School of Medicine, Miami, Florida

\begin{abstract}
The Department of Neurological Surgery at the University of Miami/Jackson Memorial Hospital's legacy of patient care, teaching, and research in the neurosciences extends over a period of 50 years. The department's founder was Dr. David Reynolds. The subsequent chairman, Dr. Hubert Rosomoff, formed a solid foundation that helped put the department on the map. Drs. Barth Green and Roberto Heros, the immediate past chair and co-chairman, garnered both national and international attention for the department. Dr. Green focused his career on complex spine and spinal cord disorders, and was pivotal in creating the world's largest research center for spinal cord injuries. Dr. Heros is a master educator and pioneer neurovascular surgeon, as well as a former president of several neurosurgical national and international organizations. In aggregate, the department has made major contributions to the foundations of neurosurgery.

https://thejns.org/doi/abs/10.3171/2016.4.JNS152356

KEY WORDS history; University of Miami; The Miami Project; spinal cord injury
\end{abstract}

$\mathrm{T}$ HE southern areas of Florida and the city of Miami had to await the establishment of the railway - created by Henry Flagler at the urging of Julia Tuttlein 1896 for its development. The marshy swamps soon transformed into the cities of Miami and Miami Beach, and the population of South Florida rose exponentially. It is very important to remember that the city of Miami's history and its health system are barely a century old. The first neurosurgeon to set up practice in the state of Florida was James Lyerly in Jacksonville in 1934. In 1940, Dr. Lyerly brought in Dr. Tracey Haverfield as an associate. After serving in the military from 1942 to 1945, Dr. Haverfield decided to relocate to Miami. He opened the second neurosurgical office in Florida, and he was the first neurosurgeon to practice in Miami. The Department of Neurosurgery began at the University of Miami in 1959, and it became the state's first neurological surgery training program. The Department of Neurological Surgery at the University of Miami Miller School of Medicine commemorates more than half a century in patient care, teaching, and research by paying tribute to and reflecting on the accomplishments and achievements of its faculty. This article reviews the history of the University of Miami School of Medicine and the Department of Neurological Surgery, and the legacy of several of its innovative leaders, as well as the role they played in shaping the department's history and their contributions to the field of neurosurgery.

\section{The Beginning}

The University of Miami was established in 1926, and from its inception there was interest in including a medical school. However, the timing was not optimal; shortly after its opening, the campus was ravaged by the "great" hurricane of 1926, which remains the costliest US hurricane ever when adjusted for inflation, population, and wealth normalization-yielding a cost of nearly US $\$ 165$ billion in current dollars. The Great Depression and World War II followed this catastrophe. It would take another 2 decades before the University revisited the idea of a medical school. The university's announcement of its plan to build a medical school was greeted with a series of political conflicts. At issue was the location of the medical school and state support for a private institution such as the University of Miami. ${ }^{5}$ As a result of the disagreements, in May of 1947 the University of Miami voted to "postpone indefinitely" its plans to create a medical school. While continuing the political negotiations for state support for a medical school, the University of Miami leadership formed a partnership with the Miami Veterans Administration (VA) Hospital to develop the University of Miami/VA Hospital Medical Research Unit. This provided basic science infrastructure that could later be incorporated into a medical school. After state support was finally assured, on March 10, 1952, the University Board of Trustees established the University of Miami School of Medicine as the first medical school

ABBREVIATIONS AANS = American Association of Neurological Surgeons; ahSCs = autologous human Schwann cells; CNS = Congress of Neurological Surgeons; LIFE $=$ Leaders in Furthering Education; $\mathrm{SCl}=$ spinal cord injury; VA = Veterans Administration; WFNS = World Federation of Neurosurgical Societies.

SUBMITTED October 14, 2015. ACCEPTED April 11, 2016.

INCLUDE WHEN CITING Published online June 24, 2016; DOI: 10.3171/2016.4.JNS152356. 
in the state of Florida. Initial teaching was carried out in what had been servants' quarters of the Biltmore Hotel, which at that time was housing the VA Hospital. On December 18, 1952, Jackson Memorial Hospital was designated the teaching hospital for the medical school.

"By 1975, the University of Miami School of Medicine/ Jackson Memorial Medical Center had grown to become the largest of its kind in the southeast and the fifth largest in the nation. The school was the tenth largest medical school with the twelfth largest faculty." ${ }^{20}$ Today, the medical campus, located at the intersection of several innercity metropolitan Miami communities, occupies almost 68 acres in the 153-acre University of Miami/Jackson Memorial Medical Center complex. It includes 3 University of Miami-owned hospitals: University of Miami Hospital, Sylvester Comprehensive Cancer Center, and Anne Bates Leach Eye Hospital. Jackson Memorial Hospital is now one of the largest and busiest hospitals in the US, with 1892 beds, ${ }^{21}$ and it is the only Level 1 adult and pediatric trauma center in Miami-Dade County. The leadership at the medical center was also instrumental in the creation of the Ryder Trauma Center, the largest and busiest trauma center in the nation. The University of Miami Medical Center, including Jackson Memorial Hospital and the University of Miami Hospital, collectively form the third largest medical center in the nation. ${ }^{2}$ On December 1, 2004, with a historic gift of \$100 million from the family of the late Leonard Miller, the medical school was renamed the Leonard M. Miller School of Medicine.

In 1954, the Department of Surgery was established as one of the first 4 clinical departments at the medical school, and in 1959 neurosurgery became a division of the Department of Surgery. In 1959, shortly after obtaining divisional status, the Neurosurgical Training Program was established by Dr. David Reynolds, the first chairman of the Division of Neurosurgery. The division received accreditation in 1965, and by 1971, under the leadership of W. Dean Warren, the division was granted departmental status. Currently, the Department of Neurological Surgery performs more than 4500 major neurosurgical procedures annually, and is hoping to expand the surgical practice by using telemedicine to collaborate with global partners.

\section{Formative Years of Neurosurgery \\ David H. Reynolds (1962-1971)}

David Reynolds served as the interim chair for the Department of Surgery from 1961 to 1963 (Fig. 1). In 1962 he was named the first professor of neurological surgery, and in 1969 he was appointed as the first chairman of the Division of Neurosurgery. He had established the Neurosurgical Training Program in 1959, and continued to supervise patient care and the Neurosurgical Education Program until his retirement in 1971. He unfortunately died of a malignant brain tumor.

\section{Hubert L. Rosomoff (1971-1994)}

After the retirement of Dr. Reynolds in 1971, Dr. Hubert Rosomoff was recruited from the chairmanship at Albert Einstein College of Medicine to become a professor and the second chairman of the newly autonomous Depart-

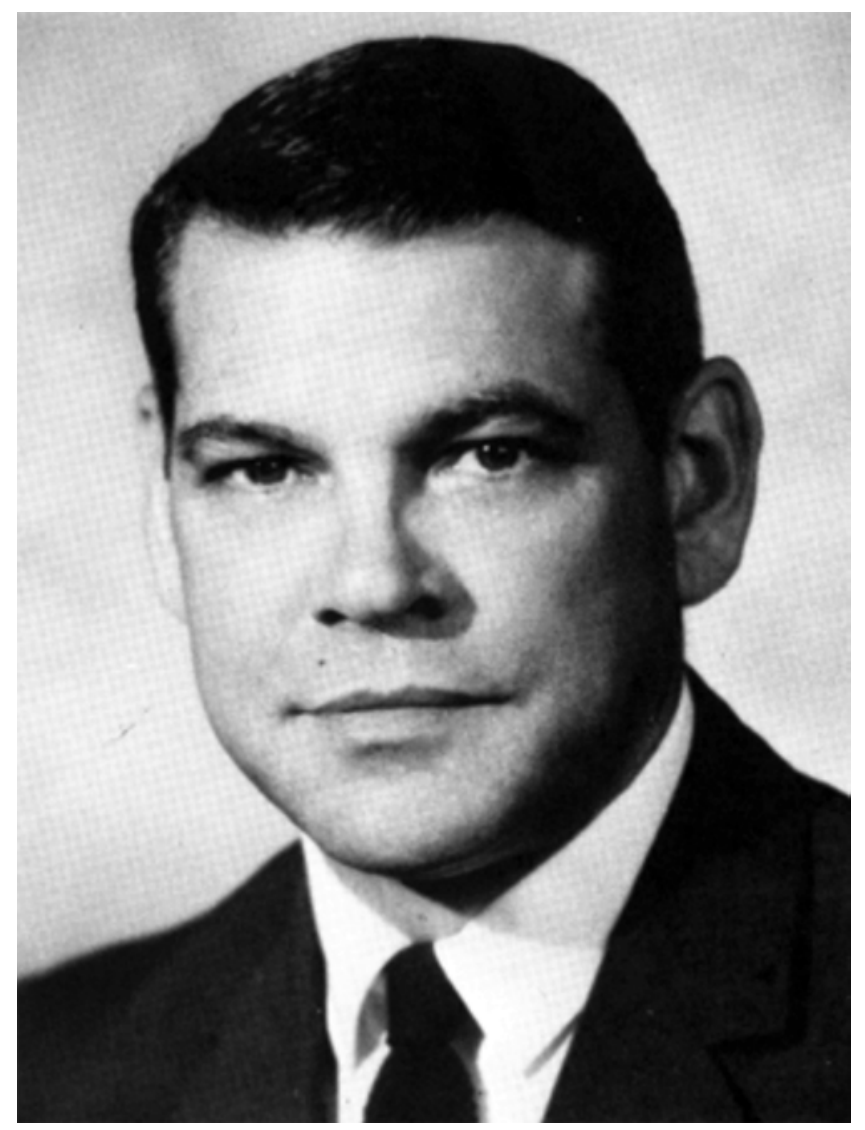

FIG. 1. David H. Reynolds, the first chairman of the Division of Neurosurgery at the University of Miami School of Medicine. Copyright Department of Neurological Surgery, Miami Miller School of Medicine. Published with permission.

ment of Neurological Surgery at the University of Miami School of Medicine (Fig. 2). The creation of departmental status under his financial control was one of the main attractions in taking on this new challenge in Miami. Dr. Rosomoff served as departmental chairman and director of the residency program until 1994.

Dr. Rosomoff started his medical career in 1952, as a graduate of Hahnemann Medical College in Philadelphia, and is a 1959 graduate of the Columbia Presbyterian Medical Center and the Neurological Institute of New York neurosurgery training program. He later received a D.Med.Sc. degree in physiology from the Columbia University College of Physicians and Surgeons. In 1959, he joined the faculty of the University of Pittsburgh School of Medicine as clinical assistant professor, and chief of neurological surgery at the VA Hospital. He remained at the University of Pittsburgh until 1966, where he was promoted to professor.

Dr. Rosomoff's contributions to the field of neurosurgery are numerous, and he became an innovator in pain medicine. His early research focused on the field of head injury, and later added an emphasis on intracranial vascular surgery. While in Pittsburgh, he introduced the technique of hypothermia for the treatment of vascular lesions and brain injuries. Later on in his career Dr. Rosomoff 


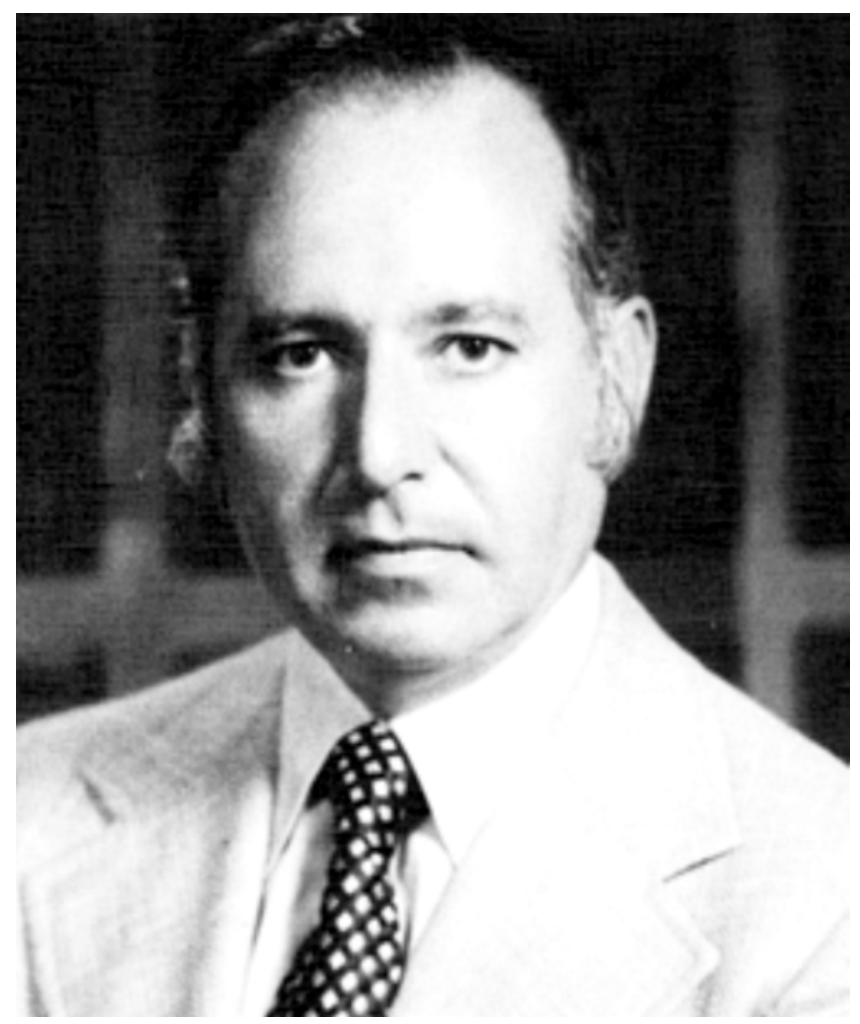

FIG. 2. Hubert L. Rosomoff, the second chairman of the Department of Neurological Surgery at the University of Miami School of Medicine. Copyright Department of Neurological Surgery, Miami Miller School of Medicine. Published with permission.

focused his research on pain, and introduced the technique of percutaneous radiofrequency cordotomy (Fig. 3) for intractable pain, which would later replace the slow and imprecise open surgical method. Some of the many faculty recruits who achieved national acclaim during Dr. Rosomoff's tenure included Dr. Larry Page, Dr. Barth Green, Dr. John Van Buren from the NIH, Dr. Howard Landy, Dr. Phillip Villanueva, Dr. Linda Sternau, and late in his career, Dr. Sydney Peerless. In 1974, Dr. Rosomoff founded the University of Miami's Comprehensive Pain and Rehabilitation Center, a Center of Excellence for the treatment of pain. The center's work is based on a multidisciplinary model of functional restoration and behavior modification. ${ }^{13}$ Dr. Rosomoff served as the center's medical director, and his wife Renee Rosomoff served as the program director. ${ }^{3}$

In 1994, Dr. Rosomoff retired as chairman to concentrate his efforts on the Pain Center, and was named professor and chairman emeritus of the Department of Neurological Surgery. In 2003, the center was renamed the Rosomoff Comprehensive Pain Center to pay tribute to him and his wife. In 1997, the Hubert Rosomoff Endowment Lectureship Fund was created to memorialize his work. The fund established the Rosomoff Research Day, an annual event held by the Department of Neurological Surgery, which includes presentations of original research by residents, fellows, clinical faculty, and visiting professors. A prize is awarded to the resident presenting the best paper of the day.

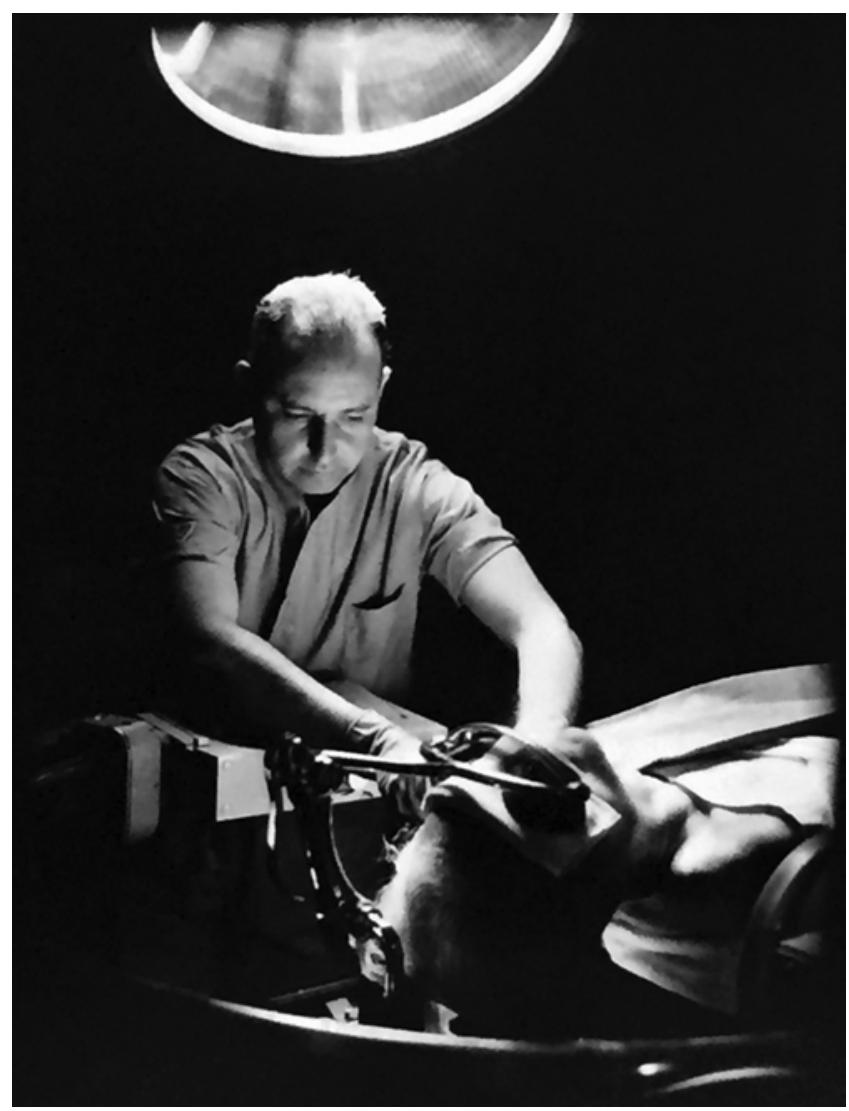

FIG. 3. Dr. Rosomoff performing a cordotomy in his early years. Copyright Department of Neurological Surgery, Miami Miller School of Medicine. Published with permission.

\section{Larry K. Page (1971-1995)}

Dr. Page joined the Department of Neurological Surgery in 1971, and served as vice chairman until 1995. A 1958 graduate of Louisiana State University School of Medicine, he completed his residency and served as faculty at the Children's Hospital Medical Center and Peter Bent Brigham Hospital in Boston before joining the faculty at the University of Miami. Dr. Page is credited with establishing the Division of Pediatric Neurosurgery a year after joining the faculty at the University of Miami. At the time, it was the only pediatric neurosurgery program in the state of Florida. Dr. Page also played an important role in establishing an additional clinical dimension to the department.

\section{New Era in Neurosurgery}

\section{Barth A. Green (1995-present)}

Dr. Green joined the faculty at the University of Miami in 1975, and was appointed chair of the department in 1994 (Fig. 4). A 1969 Alpha Omega Alpha graduate of Indiana University School of Medicine, his decision to enter neurosurgery was heavily influenced by his dear mentor Dr. Julius Goodman. He returned home to Chicago, and in 1975 graduated from Northwestern University Medical School's neurosurgery training program. His mentors included his chairs at Northwestern, Drs. Bucy and Rai- 


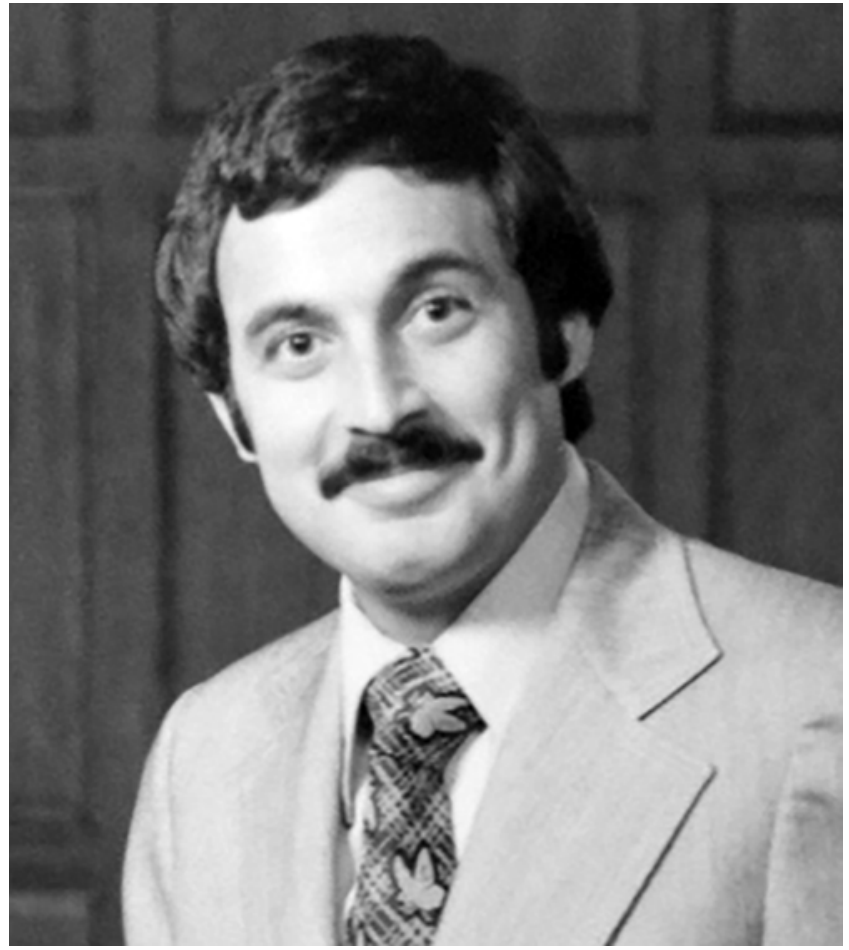

FIG. 4. Barth A. Green, the third chairman of the Department of Neurological Surgery at the University of Miami Miller School of Medicine. Copyright Department of Neurological Surgery, Miami Miller School of Medicine. Published with permission.

mondi, and he was also deeply influenced by neurosurgical role models Edgar Siquierra and Ivan Ciric.

Dr. Green is from a family of physicians who were dedicated to serving the disadvantaged. Working as a research assistant in the spinal cord injury (SCI) research laboratory, Dr. Green was influenced by the courage displayed by paraplegics who volunteered in the lab. This experience helped shape his desire to find effective treatments and a cure for paralysis. Upon joining the faculty at the University of Miami he was tasked with creating an SCI center and enhancing the SCI program at the Miami VA Hospital. ${ }^{22}$ The idea of kinetic therapy for the treatment of SCI was fueled by the energy and synergy of Dr. Green., ${ }^{1,6,9,15}$ The RotoRest treatment table, as it was originally named, was essentially a bed with reinforced gowns and balls of yarn that would allow the patient to be turned and to lie in one position without being uncomfortable. Sir Ludwig Guttmann at Stoke Mandeville Hospital in England pioneered early versions of the static bed. After a visit to this renowned SCI center in the 1970s, Dr. Green encouraged his longtime colleague Jim Leininger, MD, to start a company (that began in a couch factory) to make the kinetic version of the bed. The original company founded in 1976, Kinetic Concepts, made the original bed that was used at Northwestern University, where Dr. Green was a resident at the time. The current RotoRest is manufactured by $\mathrm{KCI}$ Therapeutic Support Systems, San Antonio, Texas. Similarly, the Miami J collar, manufactured originally by Jerome Medical and now by Ossur, was initially tested and refined at the busy SCI unit at Jackson Memorial Hospital, and the name Miami J (for Jackson) was initiated then and has remained to this day.

Dr. Green is a pioneer neurosurgeon who was one of the first in the field to focus on complex spine and spinal cord disorders. He is a founding member of the American Association of Neurological Surgeons (AANS)/Congress of Neurological Surgeons (CNS) Joint Section on Disorders of the Spine and Peripheral Nerves. In addition to establishing a very busy clinical practice, some of his many accomplishments in the surgical arena include the use of intraoperative ultrasound in spine surgery, the adoption of the cervical laminoplasty technique in the US for cervical spinal stenosis and myelopathy, describing the technique of spinal cord untethering and duraplasty for syringomyelia, and the use of intraoperative spinal angiography for Type I dural fistula. Finally, he gained recognition for the surgical treatment of intradural spinal tumors. ${ }^{4,10-12,14-16,19}$

\section{The Miami Project to Cure Paralysis}

Ten years after arriving at the school of medicine, one of Dr. Green's many visions was soon to be realized. It took tragedy to start the momentum for the work to turn the tide against paralysis. Marc Buoniconti sustained a serious high cervical SCI while playing college football at The Citadel, the military college in South Carolina. While treating Mr. Buoniconti, Dr. Green and Marc's father, Nick Buoniconti (an NFL Hall of Fame middle linebacker for the Super Bowl champion Miami Dolphins-including the undefeated 1972 team), decided to partner to find a cure for paralysis. It was believed that the best chance for success was to create an institute whose sole focus was to bring bench-to-bedside research to patients living with SCI. In 1985, with the commitment and involvement of the Buoniconti family, the Miami Project to Cure Paralysis was established. The name came in part from the concept of the Manhattan Project, in which a group of scientists came together to create the world's first nuclear weapons during World War II. Although the goals are completely different, the process of bringing together a group of scientists for a common goal-to cure paralysis-was how the name evolved. Although the name and Miami Project logo, of a man getting up from a wheelchair in a series of steps, have been criticized as being overly ambitious, these have endured, and The Miami Project is now the world's largest and most comprehensive research center dedicated to research in the field of paralysis and SCI. The University of Miami Miller School of Medicine has designated the Miami Project to Cure Paralysis a Center of Excellence.

The Miami Project has been fortunate to attract some of the world's top neuroscientists. The original scientific director was Dr. Äke Sager (1985-1987), who came from the Karolinska Institute (Fig. 5A). Drs. Mary and Richard Bunge were recruited from Washington University in St. Louis, and Dr. Richard Bunge served as the second scientific director until his untimely death in 1996 (Fig. 5B). Their research on rat, primate, and autologous human Schwann cells (ahSCs), SCI, and the pathology of human SCI were among the many exciting areas of research that laid the foundation for later clinical trials with ahSCs. The current director, Dr. W. Dalton Dietrich (1997-present), was recruited to Miami from one of the preeminent labo- 


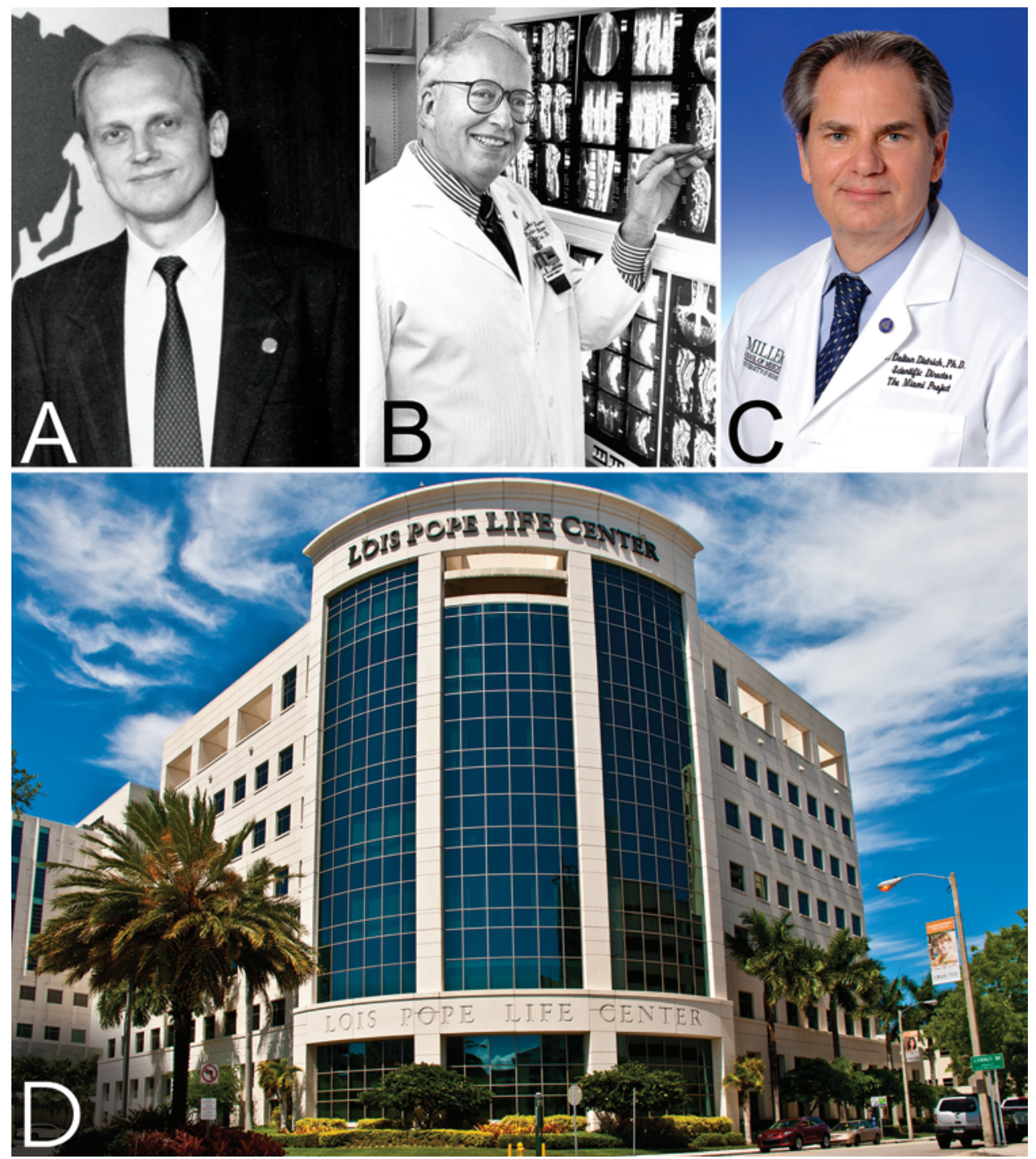

FIG. 5. A: Äke Sager, the original scientific director of The Miami Project to Cure Paralysis. B: Richard Bunge, the second scientific director of The Miami Project to Cure Paralysis. C: W. Dalton Dietrich, the current scientific director of The Miami Project to Cure Paralysis. D: Lois Pope LIFE Center, home of The Miami Project to Cure Paralysis. Copyright Department of Neurological Surgery, Miami Miller School of Medicine. Published with permission. Figure is available in color online only.

ratories in neurotrauma at the University of Virginia (Fig. 5C). One of Dr. Dietrich's many contributions includes the establishment of modest hypothermia as a neuroprotective strategy for experimental SCI. Today, participants in the Miami Project to Cure Paralysis hope to revolutionize SCI research by evaluating the safety of transplanting ahSCs in patients with acute and chronic spinal cord and peripheral nerve injuries. Other clinical trials include the use of intravascular modest hypothermia after cervical SCI, neural stem cells for chronic SCI and ahSCs for peripheral nerve injuries with lengthy gaps.

In early 2016, The Christine E. Lynn Rehabilitation Center for The Miami Project to Cure Paralysis at the University of Miami/Jackson Memorial Medical Center broke ground, with the hospital expected to open in 2018. It will provide a state of the art rehabilitation facility for patients from South Florida and around the world who have SCIs and who need other forms of rehabilitation services. The Lois Pope Leaders in Furthering Education (LIFE) Center is the home of the Miami Project to Cure Paralysis (Fig. 5D). It was named to honor the generosity of Lois Pope, who donated a \$10 million gift to the university to establish the Center. The Center is the most advanced research facility for SCIs and neurological diseases and disorders.

\section{Humanitarian Efforts}

In 1994, Dr. Green helped to found Project Medishare, the main goal of which is to provide sustainable health care in Haiti. The mission took on an even stronger role on January 12, 2010, when a massive 7.0-magnitude earthquake struck Haiti, leaving a quarter of a million people dead, 1.5 million people homeless, and the nation's already shaky infrastructure devastated. Project Medishare transitioned the field hospital in June of 2010 into an ex- 


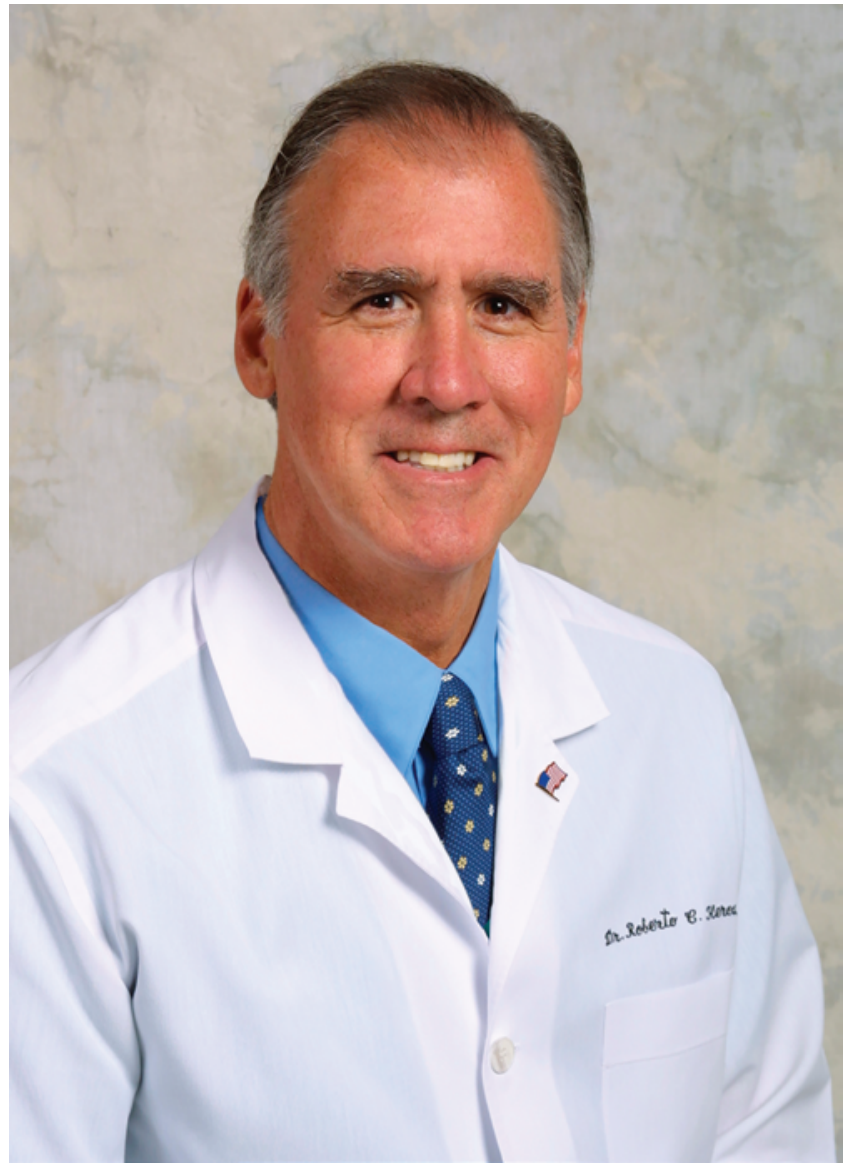

FIG. 6. Roberto C. Heros, former co-chairman of the Department of Neurological Surgery at the University of Miami Miller School of Medicine. Copyright Department of Neurological Surgery, Miami Miller School of Medicine. Published with permission. Figure is available in color online only.

isting small community nonprofit hospital and upgraded the equipment and operating rooms to create the first critical care, trauma, and rehabilitation hospital in Haiti. Dr. Green also cofounded the University of Miami Global Institute for Community Health and Development, a university-wide program that focuses on improving health care in the Western hemisphere and beyond. Drs. Green and Ragheb are focused on creating a neurosurgical training program for Haiti as well. Dr. Green has been awarded several humanitarian awards; one of the most important was the 2011 Humanitarian Award from the AANS. Another very important humanitarian effort cofounded by Dr. Green and Harry Horgan was the creation of ShakeA-Leg Miami in 1990. Shake-A-Leg was originally a summer recreation program in Newport, Rhode Island, and it is now an important part of the South Florida community. ${ }^{22}$ Shake-A-Leg provides education along with recreation for adults and children with physical, mental, and financial challenges.

\section{Roberto C. Heros (1995-present)}

Roberto C. Heros joined the University of Miami in 1995 as professor and co-chairman of the Department of
Neurological Surgery, as well as the residency program director (Fig. 6). Dr. Heros was born in Havana, Cuba, and participated as a paratrooper in the Bay of Pigs invasion. After spending 2 years in a Cuban prison he was released as part of an exchange with the US government. A 1968 graduate of the University of Tennessee Medical School, he graduated first in his class.

Dr. Heros completed his internship and neurosurgical residency at Massachusetts General Hospital, and after completion of his residency in 1977, he moved to the University of Pittsburgh as an assistant professor. In 1980 he returned to Harvard/Massachusetts General Hospital, where he became director of cerebrovascular surgery and professor of neurosurgery. In 1989 he moved to the University of Minnesota as the Lyle A. French Professor and chairman of the Department of Neurosurgery. While at the University of Minnesota, he served as acting chairman of the Departments of Neurology and Urology, and as vice chair of the Medical School Practice Plan.

Interestingly, both Drs. Heros and Green competed for the same chairman position at the University of Miami in 1994. Although Dr. Green was selected by the search committee to become chairman, he realized that mastering each aspect of running the department, including education and development of a top-notch residency program, would be difficult to do on his own, and that the new departmental structure would be best served with Dr. Heros working alongside him. In luring Dr. Heros from Minnesota, the creation of a co-chair position was key. Dr. Heros saw the University of Miami as an opportunity to return to his Cuban/Latin American roots, and to focus on scholarly pursuits and neurosurgical education. Therefore, the partnership between Drs. Green and Heros was ideal; the strengths of one covered for the weaknesses of the other. Together they achieved more than what they could have achieved individually. It should be noted that a similar model had already developed at the Barrow Neurological Institute under the leadership of Drs. Spetzler and Sonntag. This model also insures both strong spinal and cranial representation in the department.

During his tenure at the University of Miami, Dr. Heros developed and founded the University of Miami's International Health Center. His expertise in cerebrovascular disease has earned him international status. Dr. Heros is a member of more than 50 international and national associations, and is chairman of the Neurovascular Committee of the World Federation of Neurosurgical Societies (WFNS). He has also served as president of the AANS, and has founded and served as past chairman of the National "Brain Attack" Coalition and the Neurovascular Committee of the WFNS. Dr. Heros has also served as vice president of the CNS and as president of the AANS, the American Academy of Neurological Surgeons, and the World Congress of the WFNS. In 2007, he was awarded the Parker J. Palmer "Courage to Teach" award of the Accreditation Council for Graduate Medical Education (ACGME), and in 2010 he won the Cor Vitae Award of the American Heart Association for his contributions to stroke care. He is also the recipient of the 2010 AANS Cushing Medal, the highest award given to a neurosurgeon by the AANS.

Dr. Heros will always be recognized for his honesty and 


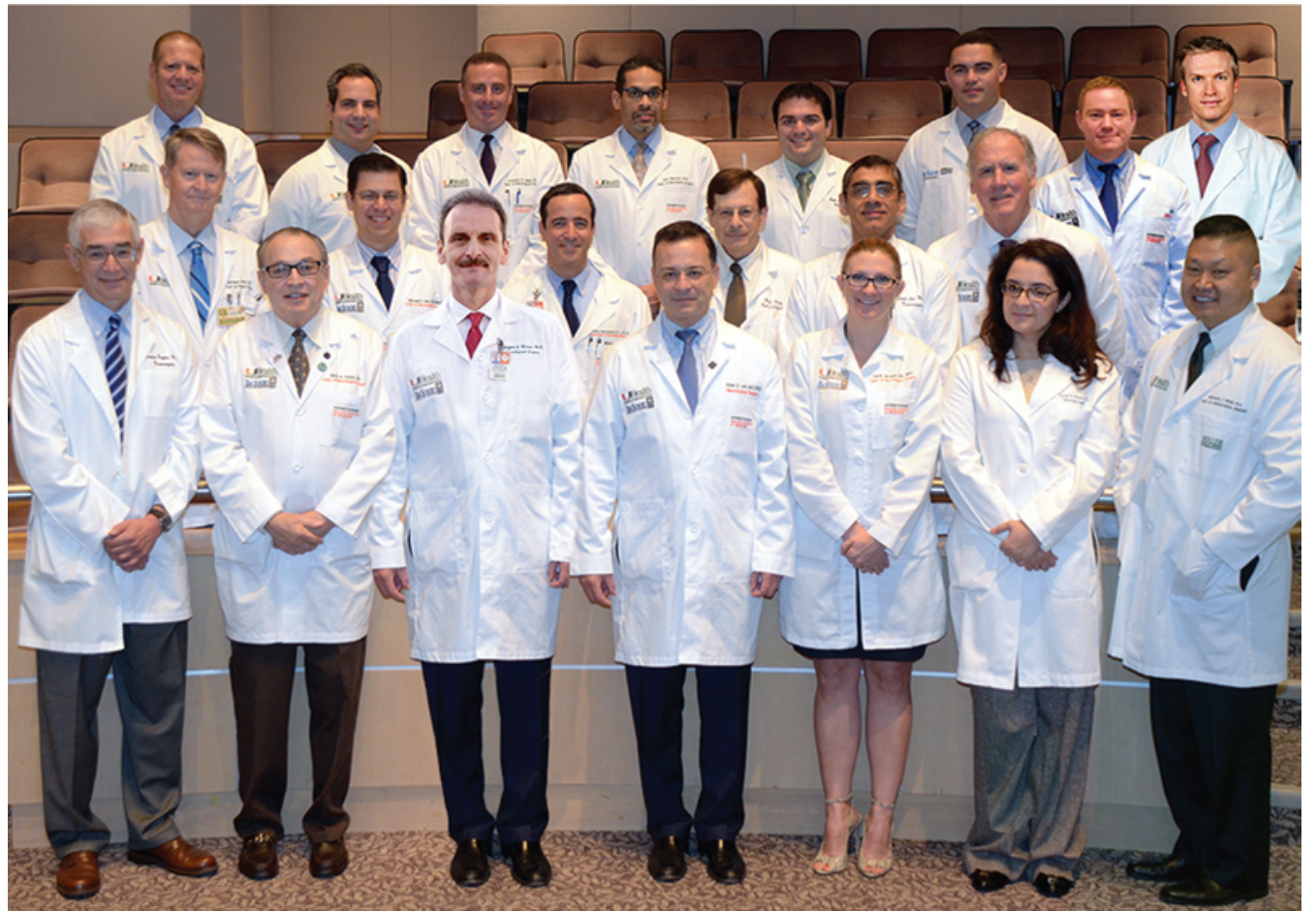

FIG. 7. Current Department of Neurological Surgery faculty at the University of Miami Miller School of Medicine. Copyright Department of Neurological Surgery, Miami Miller School of Medicine. Published with permission. Figure is available in color online only.

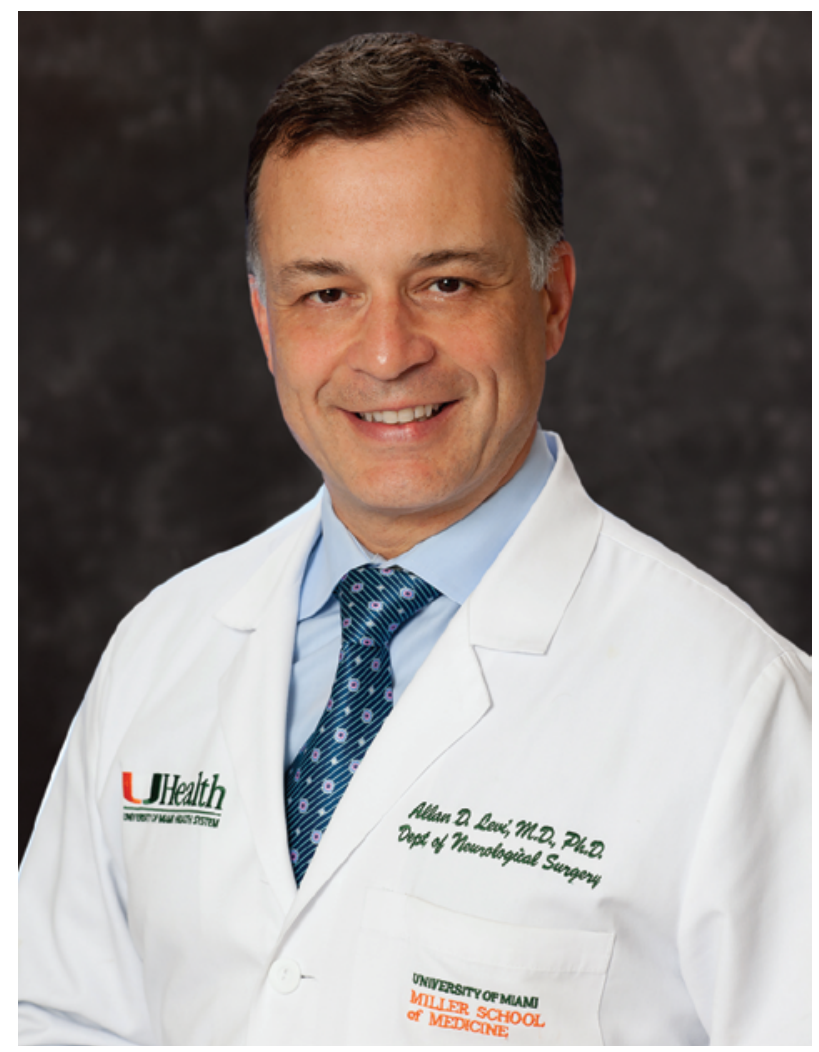

FIG. 8. Allan D. Levi, the new chairman of the Department of Neurological Surgery at the University of Miami Miller School of Medicine. Copyright Department of Neurological Surgery, Miami Miller School of Medicine. Published with permission. Figure is available in color online only.

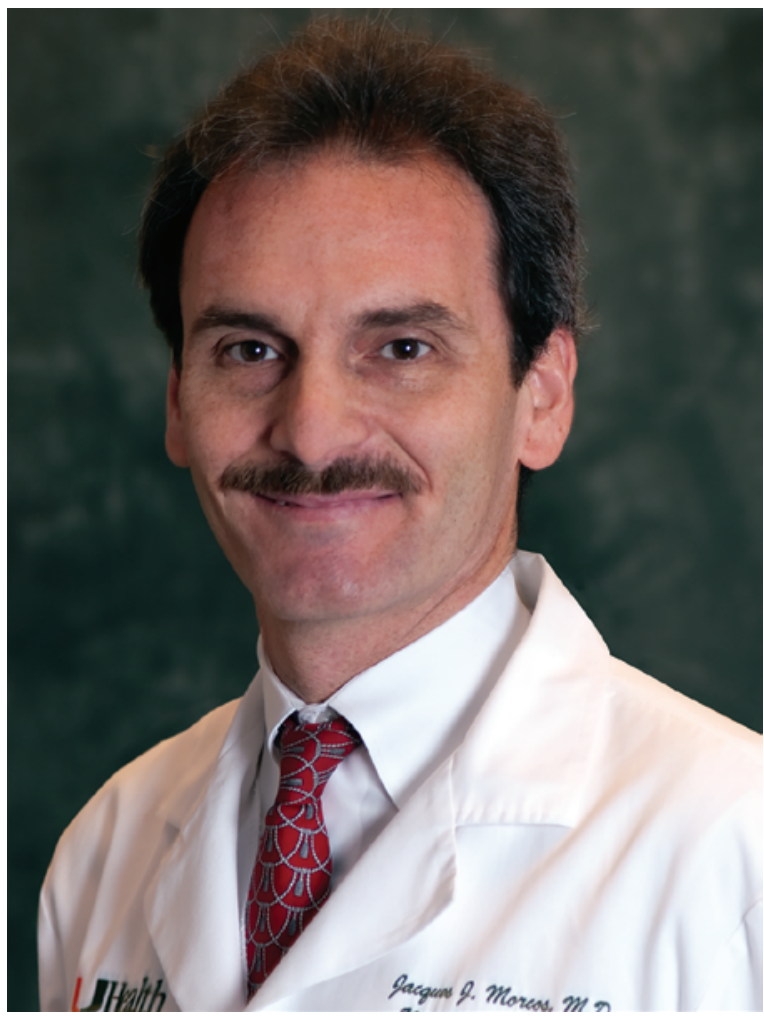

FIG. 9. Jacques J. Morcos, the new co-chairman of the Department of Neurological Surgery at the University of Miami Miller School of Medicine. Copyright Department of Neurological Surgery, Miami Miller School of Medicine. Published with permission. Figure is available in color online only. 
TABLE 1. Residents trained at the University of Miami Miller School of Medicine's neurosurgery residency program

\begin{tabular}{|c|c|c|}
\hline Name & $\begin{array}{c}\text { Yr of } \\
\text { Graduation }\end{array}$ & Current Location \\
\hline Dale Johns & 1966 & Fort Walton Beach, FL; PP \\
\hline Theodore Sarafoglu & 1967 & Retired; PP \\
\hline Pedro Albanes & 1967 & Hialeah, FL; PP \\
\hline Alfred Murrle & 1967 & Deceased \\
\hline Jesus Hiromato & 1972 & Retired; PP \\
\hline Raul V. Rivet & 1973 & Retired; PP \\
\hline Gary J. Lustgarten & 1973 & Miami, FL; PP \\
\hline Robert Jacobson & 1975 & Coral Gables, FL; PP \\
\hline Mihai D. Dimancescu & 1976 & Retired; PP \\
\hline Franklin T. Welch & 1978 & Retired; PP \\
\hline Joseph P. Coladonato & 1978 & Retired; PP \\
\hline William C. Bergman & 1979 & San Jose, CA; PP \\
\hline Jaime Rosenthal & 1980 & Retired; PP \\
\hline Lewis S. Snitzer & 1980 & Retired; PP \\
\hline Aldo F. Berti & 1980 & Miami, FL; PP \\
\hline Phillip A. Villanueva & 1982 & Philadelphia, PA; Ac \\
\hline Judith Murovic & 1983 & Stanford, CA; Ac \\
\hline Jorge L. Acevedo & 1983 & Fargo, ND; PP \\
\hline Gustavo J. Arriola & 1984 & Kissimmee, FL; PP \\
\hline Mark N. Weissman & 1985 & Marshfield, Wl; PP \\
\hline Sergio M. Gonzalez-Arias & 1985 & Miami, FL; PP \\
\hline Arnold C. Lang & 1986 & Hollywood, FL; PP \\
\hline Luis R. Pagan & 1987 & Hialeah, FL; PP \\
\hline Howard J. Landy & 1987 & Miami, FL; Ac \\
\hline Ignacio A. Magana & 1988 & Retired; PP \\
\hline Abraham Mintz & 1989 & Trumbull, CT; PP \\
\hline John C. Amann & 1989 & Winter Haven, FL; PP \\
\hline Dirk G. Franzen & 1990 & Unknown \\
\hline Michael R. Egnor & 1991 & Stony Brook, NY; Ac \\
\hline Keith Anthony Tucci & 1992 & Greenville, NC; PP \\
\hline Charles H. Bill & 1992 & East Lansing, Ml; PP \\
\hline George C. Ibars & 1993 & Miami, FL; PP \\
\hline Guillermo A. Pasarin & 1993 & Sunrise, FL; PP \\
\hline Richard S. Kyle & 1994 & Bentonville, AR; PP \\
\hline Frederick B. Gutman & 1994 & Stony Brook, NY; Ac \\
\hline John F. Keller & 1995 & Grand Rapids, Ml; PP \\
\hline Anthony James Hall & 1995 & Miami, FL; PP \\
\hline Carlos A. David & 1996 & Burlington, MA; Ac \\
\hline Paul K. Ratzker & 1996 & Union, NJ; PP \\
\hline Brian Wieder & 1997 & Casper, WY; PP \\
\hline Nizam Razack & 1997 & Orlando, FL; PP \\
\hline Katshiro Kure & 1998 & Tokyo, Japan; PP \\
\hline Kurt D. Bangerter & 1998 & Ogden, UT; PP \\
\hline Thomas T. Lee & 1999 & Tarrytown, NY; PP \\
\hline Ran Vijai P. Singh & 2000 & Norfolk, VA; PP \\
\hline Omar F. Jimenez & 2000 & Scottsbluff, NE; PP \\
\hline Jose M. Arias & 2000 & Owensboro, KY; PP \\
\hline
\end{tabular}

CONTINUED IN NEXT COLUMN »
» CONTINUED FROM PREVIOUS COLUMN

TABLE 1. Residents trained at the University of Miami Miller School of Medicine's neurosurgery residency program

\begin{tabular}{|c|c|c|}
\hline Name & $\begin{array}{c}\text { Yr of } \\
\text { Graduation }\end{array}$ & Current Location \\
\hline Jonathan Jagid & 2001 & Miami, FL; Ac \\
\hline Philipp R. Aldana & 2001 & Jacksonville, FL; Ac \\
\hline Chad Prusmack & 2002 & Lone Tree, CO; PP \\
\hline Hisham Al-Khayat & 2003 & Salmiya, Kuwait; PP \\
\hline Imad Abumeri & 2003 & Bakersfield, CA; PP \\
\hline Elizabeth Vitarbo & 2004 & Jacksonville, FL; Ac \\
\hline Kapil Moza & 2004 & Thousand Oaks, CA; PP \\
\hline Sanjiv Bhatia & 2004 & Miami, FL; Ac \\
\hline Ramin Javahary & 2005 & Long Beach, CA; PP \\
\hline Mustafa Baskaya & 2005 & Madison, Wl; Ac \\
\hline Andrew Jea & 2006 & Houston, TX; Ac \\
\hline Mohammad Aziz-Sultan & 2006 & Boston, MA; Ac \\
\hline Joseph Wehman & 2007 & Orlando, FL; PP \\
\hline Rishi Sheth & 2007 & Delray Beach, FL; PP \\
\hline Stacey Quintero-Wolfe & 2008 & Winston-Salem, NC; Ac \\
\hline Ryan Trombly & 2008 & Oakwood, IL; PP \\
\hline Glen Manzano & 2009 & Miami, FL; Ac \\
\hline Anitha Nimmagada & 2009 & Rockford, IL; PP \\
\hline Hamad Farhat & 2010 & Chicago, IL; PP/Ac \\
\hline Ted Brindle & 2010 & Roseville, CA; PP \\
\hline David Benglis & 2011 & Atlanta, GA; PP \\
\hline Christopher Demassi & 2011 & Hollywood, FL; PP \\
\hline Asterios Tsimpas & 2012 & Maywood, IL; Ac \\
\hline M. Samy Elhammady & 2012 & Miami/Tampa, FL; Ac/PP \\
\hline Garrett Zoeller & 2012 & Portland, OR; PP \\
\hline Charles Bowie & 2013 & Baton Rouge, LA; PP \\
\hline Brian Hood & 2013 & Houston, TX; Mil \\
\hline Faiz Ahmad & 2014 & Atlanta, GA; Ac \\
\hline Ramzi Ashour & 2014 & Austin, TX; Ac \\
\hline Jeremiah Johnson & 2014 & San Antonio, TX; Ac \\
\hline Gabriel Widi & 2015 & Miami, FL; PP \\
\hline Mohammed F. Khan & 2015 & Oradell, NJ; PP \\
\hline Michael Thambuswamy & 2015 & Tulsa, OK; PP \\
\hline Seth Hayes & 2016 & Raleigh, NC; Ac \\
\hline Brandon Gaynor & 2016 & Chicago, IL, PP \\
\hline Giancarlo Perez & 2017 & Current resident \\
\hline Andrew Middleton & 2017 & Current resident \\
\hline John Serak & 2017 & Current resident \\
\hline Nicholas Ferraro & 2018 & Current resident \\
\hline Brian Snelling & 2018 & Current resident \\
\hline Joanna Gernsback & 2018 & Current resident \\
\hline Walter Jermakowicz & 2019 & Current resident \\
\hline Samir Sur & 2019 & Current resident \\
\hline Timur Urakov & 2019 & Current resident \\
\hline Simon Buttrick & 2020 & Current resident \\
\hline Karthik Madhavan & 2020 & Current resident \\
\hline
\end{tabular}

CONTINUED ON PAGE $1293 »$ 
» CONTINUED FROM PAGE 1292

TABLE 1. Residents trained at the University of Miami Miller School of Medicine's neurosurgery residency program

\begin{tabular}{lcl}
\hline \multicolumn{1}{c}{ Name } & $\begin{array}{c}\text { Yr of } \\
\text { Graduation }\end{array}$ & \multicolumn{1}{c}{ Current Location } \\
\hline Angela Richardson & 2020 & Current resident \\
\hline Stephen Shelby Burks & 2021 & Current resident \\
\hline lahn Cajigas & 2021 & Current resident \\
\hline Ashish Shah & 2021 & Current resident \\
\hline Gregory Basil & 2022 & Current resident \\
\hline Stephanie Chen & 2022 & Current resident \\
\hline Jason Liounakos & 2022 & Current resident \\
\hline
\end{tabular}

$\mathrm{Ac}=$ academic $;$ Mil $=$ military; $\mathrm{PP}=$ private practice.

integrity in neurosurgery, and is never fearful to speak his mind or "do what is right." In recognition of his dedication to teaching, a book written by Dr. Chad Prusmack and colleagues summarizes his morning teachings. ${ }^{18}$ Dr. Heros was one of the first neurosurgeons to appreciate the threat posed by interventionalists in both neurology and radiology in the neuroendovascular treatment of cerebrovascular disorders, and strongly encouraged neurosurgical trainees to pursue fellowship training in interventional neuroradiology so that these types of treatment would be under the control of neurosurgery. His many accomplishments in neurosurgery include basic research on the effects of hemodilution on experimental brain ischemia; an authoritative description of the excellent surgical results in resecting low-grade arteriovenous malformations; a description of numerous microsurgical approaches to intracranial vascular lesions, including the far-lateral approach to the skull base; the superior parietal lobule approach; and the superior temporal gyrus approach for evacuating hematomas and clipping ruptured middle cerebral artery aneurysms; as well as his long-standing relationship with the Journal of Neurosurgery, including his position as former co-chairman of the Editorial Board. ${ }^{7,8,17}$

\section{Neurosurgical Education}

The neurosurgical training program at the University of Miami Miller School of Medicine exposes residents and fellows to a diverse patient population with a wide range of neurosurgical diseases and injuries, and is designed to provide preparation for a career in academic neurosurgery. It is one of the largest neurosurgical training programs, with 21 residents and 10 fellows; 3 residents are graduated annually. The department now ranks 4th in the country in 2015 $\mathrm{NIH}$ research funding, in addition to other extensive research funding (http://www.brimr.org/NIH_Awards/2015/ NIH_Awards_2015.htm). The program primarily services a 3-county referral area of 4.5 million people, in addition to referrals from Latin America, the Caribbean, and Europe. The neurosurgical training program is a 7-year program structured into 4-month blocks, with rotations at Jackson Memorial Hospital, the VA Medical Center, the University of Miami Hospital, and Nicklaus Children's Hospital (formerly Miami Children's Hospital). These rotations provide residents with the opportunity to become
TABLE 2. External fellows trained at the University of Miami Miller School of Medicine neurosurgery program since 1993

\begin{tabular}{|c|c|c|}
\hline Name & $\begin{array}{c}\text { Yr of } \\
\text { Graduation }\end{array}$ & Location \\
\hline \multicolumn{3}{|l|}{ Vascular \& skull base fellows } \\
\hline Harold Pikus & 1998 & Lebanon, NH; PP \\
\hline Gabriel Gonzales-Portillo & 1999 & Tampa, FL; PP \\
\hline Michael Fritsch & 2000 & Kiel, Germany; Ac \\
\hline Mustafa Baskaya & 2001 & Madison, Wl; Ac \\
\hline Amit Schwartz & 2002 & Brooklyn, NY; Ac \\
\hline Chad Prusmack & 2003 & Lone Tree, CO; PP \\
\hline Greg Zipfel & 2004 & St. Louis, MO; Ac \\
\hline Ramachandra Tummala & 2005 & Minneapolis, MN; Ac \\
\hline Taro Kaibara & 2006 & Phoenix, AZ; Ac \\
\hline Eric Deshais & 2007 & Syracuse, NY; Ac \\
\hline Thomas Kretschmer & 2008 & Ulm, Germany; Ac \\
\hline Nilesh Vyas & 2009 & Fairfax, VA; Ac \\
\hline Roham Moftakhar & 2010 & Camas, WA; Ac \\
\hline Albert Kim & 2011 & St. Louis, MO; Ac \\
\hline Samy Elhammady & 2012 & Miami/Tampa, FL; PP/Ac \\
\hline Gustavo Pradilla & 2013 & Atlanta, GA; Ac \\
\hline Peter Amenta & 2014 & Philadelphia, PA; Ac \\
\hline Anthony Wang & 2015 & Seattle, WA; Ac \\
\hline Osaama Khan & 2016 & Current fellow \\
\hline \multicolumn{3}{|l|}{ Endovascular fellows } \\
\hline Ali Aziz-Sultan & 2004 & Boston, MA; Ac \\
\hline Nils Mueller-Kronast & 2006 & West Palm Beach, FL; PP \\
\hline Babak Jahromi & 2006 & Rochester, NY; Ac \\
\hline Eric Deshaies & 2007 & Syracuse, NY; PP \\
\hline Joseph Salame & 2007 & Beirut, Lebanon; Ac \\
\hline Hamad Farhat & 2008 & Chicago, IL; PP/Ac \\
\hline Stacey Quintero-Wolfe & 2009 & Winston-Salem, NC; Ac \\
\hline Roham Moftakhar & 2009 & Columbia, SC; Ac \\
\hline Eric Peterson & 2010 & Miami, FL; Ac \\
\hline Samy Elhammady & 2010 & Miami/Tampa, FL; PP/Ac \\
\hline Koji Ebersole & 2011 & Kansas City, KS; Ac \\
\hline Jeremiah Johnson & 2012 & San Antonio, TX; Ac \\
\hline Diogo Haussen & 2013 & Atlanta, GA; Ac \\
\hline Charles Bowie & 2014 & Baton Rouge, LA; PP \\
\hline Sudheer Ambekar & 2015 & India; Ac \\
\hline \multicolumn{3}{|l|}{ Trauma fellows } \\
\hline Hunaldo Villalobos & 2001 & Orlando, FL; PP \\
\hline Richard Rodgers & 2005 & Indianapolis, IN; Ac \\
\hline Joseph Chris Zacko & 2010 & Hershey, PA; Ac \\
\hline Jose Sanchez Chavez & 2011 & Miami, FL; Ac \\
\hline Ryan Kitagawa & 2013 & Houston, TX; Ac \\
\hline Kentaro Shimoda & 2014 & Tokyo, Japan; Ac \\
\hline Zachary Hickman & 2015 & New York, NY; Ac \\
\hline Ignacio Jusue Torres & 2016 & Current fellow \\
\hline \multicolumn{3}{|l|}{ Neurooncology fellows } \\
\hline Simon Hanft & 2014 & New Brunswick, NJ; Ac \\
\hline
\end{tabular}


» CONTINUED FROM PAGE 1293

TABLE 2. External fellows trained at the University of Miami Miller School of Medicine neurosurgery program since 1993

\begin{tabular}{|c|c|c|}
\hline Name & $\begin{array}{c}\text { Yr of } \\
\text { Graduation }\end{array}$ & Location \\
\hline \multicolumn{3}{|l|}{$\begin{array}{l}\text { Neurooncology fellows } \\
\text { (continued) }\end{array}$} \\
\hline Michael Ivan & 2015 & Miami, FL; Ac \\
\hline Roberto Diaz & 2016 & Montreal, QC; Ac \\
\hline \multicolumn{3}{|l|}{ Pediatric fellows } \\
\hline Sanjiv Bhatia & 2004 & Miami, FL; Ac \\
\hline Tadashi Miyagawa & 2005 & Japan; Ac \\
\hline Ernesto Coscarella & 2007 & Houston, TX; Ac \\
\hline Ernesto Coscarella & 2008 & Houston, TX; Ac \\
\hline Faiz Ahmad & 2009 & Atlanta, GA; Ac \\
\hline Samy Elhammady & 2011 & Miami/Tampa, FL; Ac/PP \\
\hline Parthasarathi Chamiraju & 2012 & Detroit, Ml; Ac \\
\hline O. Adetola Roberts & 2013 & New Orleans, LA; Ac \\
\hline Alexander Weil & 2014 & Canada; Ac \\
\hline Aria Fallah & 2015 & Los Angeles, CA; Ac \\
\hline Travis Tierney & 2016 & Current fellow \\
\hline \multicolumn{3}{|l|}{ Spine fellows } \\
\hline Parley Madsen & 1994 & Visalia, CA; PP \\
\hline Nick Vrodos & 1997 & $\begin{array}{l}\text { North Adelaide, Australia; } \\
\text { PP }\end{array}$ \\
\hline Ehud Salmon & 1998 & Israel; PP \\
\hline Brian Weider & 1998 & Casper, WY; PP \\
\hline Eric Belanger & 1999 & Bismarck, ND; PP \\
\hline William Choi & 2000 & Centennial, CO; PP \\
\hline Juan Jimenez & 2000 & Kankakee, IL; PP \\
\hline Juan Santiago Uribe & 2001 & Tampa, FL; Ac \\
\hline Steven Vanni & 2001 & Miami, FL; Ac \\
\hline Matthew McDonald & 2002 & Adelaide, Australia; PP \\
\hline Michael Wang & 2002 & Miami, FL; Ac \\
\hline Iftiqhar Haq & 2003 & Thunder Bay, Ontario; PP \\
\hline Ramon Navarro & 2004 & Abu Dhabi; PP \\
\hline Nitising Akkapong & 2005 & Bangkok, Thailand; PP \\
\hline Claudio Tatsui & 2005 & Houston, TX; Ac \\
\hline Andrew Cannestra & 2005 & Jacksonville, FL; PP \\
\hline Ricardo Cortez & 2006 & Houston, TX; PP \\
\hline Andrew Nataraj & 2006 & Edmonton, Canada; Ac \\
\hline Brad Hall & 2007 & Alcoa, TN; PP \\
\hline Ajay Pandy & 2008 & Miami, FL; PP \\
\hline Howard Levene & 2009 & Miami, FL; Ac \\
\hline Riki Trivedi & 2009 & Cambridge, UK; Ac \\
\hline Sarah Woodrow & 2009 & Kansas City, KS; Ac \\
\hline Frank Farhadi & 2009 & Columbus, $\mathrm{OH} ; \mathrm{Ac}$ \\
\hline Ann Parr & 2010 & Minneapolis, MN; Ac \\
\hline Vartan Tashijan & 2010 & Fontana, CA; PP \\
\hline Joseph Martinez & 2010 & Houston, TX; Ac \\
\hline Shah Sachin & 2011 & Rockville Centre, NY; PP \\
\hline
\end{tabular}

CONTINUED IN NEXT COLUMN »
» CONTINUED FROM PREVIOUS COLUMN

TABLE 2. External fellows trained at the University of Miami Miller School of Medicine neurosurgery program since 1993

\begin{tabular}{lll}
\hline \multicolumn{1}{c}{ Name } & $\begin{array}{c}\text { Yr of } \\
\text { Graduation }\end{array}$ & \multicolumn{1}{c}{ Location } \\
\hline $\begin{array}{l}\text { Spine fellows (continued) } \\
\text { Harshpal Singh }\end{array}$ & 2011 & Oradell, NJ; PP \\
\hline Guarav Jain & 2012 & Wynnewood, PA; Ac \\
\hline Kevin Cahill & 2012 & Charlotte, NC; Ac \\
\hline Yi Lu & 2013 & Boston, MA; Ac \\
\hline Mohamed Abdulhamid & 2013 & Scottsdale, AZ; PP \\
\hline Yoav Ritter & 2013 & Pontiac, Ml; PP \\
\hline Vasillios Dimopoulos & 2014 & Buffalo, NY; Ac \\
\hline Seth Molloy & 2014 & Columbia, SC; PP \\
\hline Ivan Stoev & 2014 & Pembroke Pines, FL; PP \\
\hline Chris Hofstetter & 2014 & Seattle, WA; Ac \\
\hline Michael Thomas & 2015 & Orlando, FL; PP \\
\hline lan Cote & 2015 & Miami, FL; Ac \\
\hline Luis Romero & 2015 & Miami, FL; Ac \\
\hline Matthew Gary & 2016 & Atlanta, GA; Ac \\
\hline Basheer Shakir & 2016 & Oklahoma City, OK; PP \\
\hline Julius Ebinu & 2016 & New York, NY; Ac \\
\hline Rajiv Saigal & 2016 & Seattle, WA; Ac \\
\hline
\end{tabular}

competent in a wide range of subspecialties, such as neurotrauma, neuroendovascular disease, neurooncology, pediatric neurosurgery, functional neurosurgery, cerebrovascular and skull-base disease, spine and peripheral nerve disorders, stereotactic surgery, and deep brain stimulation; fellowships are offered in each of these areas.

Key hires by Drs. Green and Heros that served to enhance the national reputation and educational mission early on in the program are listed chronologically. These hires included Drs. Morcos, Ragheb, Levi, Guest, Vanni, Zauner (now in private practice), Jagid, Bhatia, Sultan (now at Brigham), Sandberg (now at Memorial Hermann), Bullock, Benveniste, Levene, Wang, Komotar, Elhammady, Manzano, Peterson, Niazi, and Jernigan (Fig. 7). Additional key hires early on in the program were Nurse Practitioners Sherri Patchen and Cathy Rosenberg. These 2 original advanced registered nurse practitioners (ARNPs) are role models for the now more than 15 physician extenders who cover the 4 hospitals in the teaching system, and who have served in modified versions of their original roles for more than 50 years combined. The program has trained nearly 80 residents since its inception in 1965 (Table 1), and approximately 100 specialized fellows in spine $(>50)$, vascular and skull base $(>20)$, endovascular $(>10)$, brain tumors (3), pediatrics $(>10)$, and neurotrauma $(>10)$, particularly after 1997 (Table 2). Many of its graduates have gone on to important teaching and leadership positions throughout the US and abroad. Educational opportunities abound, with grand rounds, formal lectures, and teaching rounds. There are numerous visiting professorship opportunities; the most established is the Rosomoff visiting professorship (Table 3). 
TABLE 3. Rosomoff Research Day visiting professors

\begin{tabular}{lc}
\hline \multicolumn{1}{c}{ Visiting Professor } & Yr \\
\hline Robert Spinner, MD & 2016 \\
\hline Robert L. Martuza, MD & 2015 \\
\hline Michael Tymianski, MD, PhD & 2014 \\
\hline E. Antonio Chiocca, MD, PhD & 2013 \\
\hline Mark Bilsky, MD & 2012 \\
\hline Edward R. Laws, MD & 2011 \\
\hline Mark M. Souweidane, MD & 2010 \\
\hline Andres Lozano, MD, PhD & 2009 \\
\hline Kim Burchiel, MD & 2008 \\
\hline Henry Brem, MD & 2007 \\
\hline Edward H. Oldfield, MD & 2006 \\
\hline David G. Kline, MD & 2005 \\
\hline Mitchel S. Berger, MD & 2004 \\
\hline James T. Rutka, MD, PhD & 2003 \\
\hline
\end{tabular}

\section{The Future}

Dr. Allan D. Levi (Fig. 8) was named as the fourth chairman of the Department of Neurological Surgery in 2015. In keeping with the prior model of leadership with both strong spinal and cranial representation, Dr. Jacques J. Morcos, a longtime colleague and friend of Dr. Levi, was subsequently named co-chairman (Fig. 9). Both individuals will serve to lead the department into the future.

\section{References}

1. Askins V, Eismont FJ: Efficacy of five cervical orthoses in restricting cervical motion. A comparison study. Spine (Phila Pa 1976) 22:1193-1198, 1997

2. Becker's Hospital Review: 25 largest hospitals in America, 2015. (http://www.beckershospitalreview.com/lists/25-largesthospitals-in-america-2015.html) [Accessed April 26, 2016]

3. Dietrich WD: A tribute to Dr. Hubert L. Rosomoff: a pioneer in treatment of pain and use of hypothermia. J Neurotrauma 26:299-300, 2009

4. Eismont FJ, Green BA, Berkowitz BM, Montalvo BM, Quencer RM, Brown MJ: The role of intraoperative ultrasonography in the treatment of thoracic and lumbar spine fractures. Spine (Phila Pa 1976) 9:782-787, 1984

5. Gardner AM, Rosen LF, Sahwell PA: A Tradition of Caring: Discovery, Knowledge and Healing. Miami: University of Miami School of Medicine, 2003

6. Green BA, Green KL, Klose KJ: Kinetic therapy for spinal cord injury. Spine (Phila Pa 1976) 8:722-728, 1983

7. Heros RC, Fritsch MJ: Surgical management of middle cerebral artery aneurysms. Neurosurgery 48:780-786, 2001

8. Heros RC, Korosue K: Hemodilution for cerebral ischemia. Stroke 20:423-427, 1989

9. Keane FX: Roto-rest. BMJ 3:731-733, 1967

10. Lee TT, Alameda GJ, Gromelski EB, Green BA: Outcome after surgical treatment of progressive posttraumatic cystic myelopathy. J Neurosurg 92 (2 Suppl):149-154, 2000

11. Lee TT, Gromelski EB, Bowen BC, Green BA: Diagnostic and surgical management of spinal dural arteriovenous fistulas. Neurosurgery 43:242-247, 1998
12. Lee TT, Manzano GR, Green BA: Modified open-door cervical expansive laminoplasty for spondylotic myelopathy: operative technique, outcome, and predictors for gait improvement. J Neurosurg 86:64-68, 1997

13. Lippe PM, Fishbain DA, Gallagher RM: Hubert Rosomoff, $\mathrm{MD}, \mathrm{DMedSc}$ : pioneer in neurosurgery and pain medicine. Pain Med 10:607-610, 2009

14. Manzano G, Green BA, Vanni S, Levi AD: Contemporary management of adult intramedullary spinal tumors-pathology and neurological outcomes related to surgical resection. Spinal Cord 46:540-546, 2008

15. McGuire RA, Green BA, Eismont FJ, Watts C: Comparison of stability provided to the unstable spine by the kinetic therapy table and the Stryker frame. Neurosurgery 22:842-845, 1988

16. Montalvo BM, Quencer RM, Green BA, Eismont FJ, Brown MJ, Brost P: Intraoperative sonography in spinal trauma. Radiology 153:125-134, 1984

17. Nussbaum ES, Heros RC, Camarata PJ: Surgical treatment of intracranial arteriovenous malformations with an analysis of cost-effectiveness. Clin Neurosurg 42:348-369, 1995

18. Prusmack CJ, Baskaya MK, Jea AH, Sultan AA: Roberto C. Heros, MD. A Mentor and Teacher Like No Other. Miami: Eagle Lithographers, 2003

19. Quencer RM, Montalvo BM, Green BA, Eismont FJ: Intraoperative spinal sonography of soft-tissue masses of the spinal cord and spinal canal. AJR Am J Roentgenol 143:1307-1315, 1984

20. University of Miami School of Medicine: Interactive timeline celebrating 50 years. University of Miami School of Medicine 50th Anniversary. (http://www.med.miami. edu/50thanniversary/timeline/timeline_htm.asp) [Accessed April 26, 2016]

21. US News \& World Report Health: Hospital Rankings. Best Hospitals in Miami-Ft. Lauderdale, Fla. (http://health. usnews.com/best-hospitals/area/miami-fort-lauderdale-fl) [Accessed April 26, 2016]

22. Vertical Health: Barth A. Green, MD. SpineUniverse. (http:// www.spineuniverse.com/author/1104/green) [Accessed April $26,2016]$

\section{Disclosures}

Dr. Levi receives a teaching honorarium from Medtronic and grant support from the Department of Defense.

\section{Author Contributions}

Conception and design: all authors. Acquisition of data: all authors. Drafting the article: all authors. Critically revising the article: all authors. Reviewed submitted version of manuscript: all authors. Approved the final version of the manuscript on behalf of all authors: Levi.

\section{Supplemental Information \\ Online-Only Content}

Supplemental material is available with the online version of the article.

Appendix. http://thejns.org/doi/suppl/10.3171/2016.4.JNS152356.

\section{Correspondence}

Allan D. Levi, Department of Neurological Surgery, University of Miami Miller School of Medicine, Lois Pope LIFE Center, 1095 NW 14th Terrace (D4-6), Miami, FL 33136. email: alevi@med. miami.edu. 